\title{
Surge Pressure Mitigation in the Global Precipitation Measurement Mission Core Propulsion System
}

\author{
Ashley R. Scroggins ${ }^{1}$ and Mark D. Fiebig ${ }^{2}$ \\ NASA Goddard Space Flight Center, Greenbelt, Maryland, 20771
}

\begin{abstract}
The Global Precipitation Measurement (GPM) mission is an international partnership between NASA and JAXA whose Core spacecraft performs cutting-edge measurements of rainfall and snowfall worldwide and unifies data gathered by a network of precipitation measurement satellites. The Core spacecraft's propulsion system is a blowdown monopropellant system with an initial hydrazine load of $545 \mathrm{~kg}$ in a single composite overwrapped propellant tank. At launch, the propulsion system contained propellant in the tank and manifold tubes upstream of the latch valves, with low-pressure helium gas in the manifold tubes downstream of the latch valves. The system had a relatively high beginningof-life pressure and long downstream manifold lines; these factors created conditions that were conducive to high surge pressures. This paper discusses the GPM project's approach to surge mitigation in the propulsion system design. The paper describes the surge testing program and results, with discussions of specific difficulties encountered. Based on the results of surge testing and pressure drop analyses, a unique configuration of cavitating venturis was chosen to mitigate surge while minimizing pressure losses during thruster maneuvers. This paper concludes with a discussion of overall lessons learned with surge pressure testing for NASA Goddard spacecraft programs.
\end{abstract}

\section{Introduction}

W ater hammer is a potentially damaging event that occurs in a pipe when any event disturbs the steady state fluid. Water hammer can occur in a number of situations, such as opening a latch valve, closing a latch valve, opening a thruster valve, or closing a thruster valve. Currently, propulsion engineers at the NASA Goddard Space Flight Center (GSFC) focus on pressure surges occurring when latch valves are opened to prime thruster manifolds. At system priming, a high pressure differential exists across the latch valve. The propellant fills the lines at a high flow rate, creating the potential for high surge pressures when the fluid hits the dead end.

Many system parameters affect the magnitude of pressure surges by also affecting the fluid momentum. For example, the length and diameter of the propellant feed lines affects surge pressures: longer lines and lines with greater inner diameters result in higher surge pressures. Driving pressure also affects surge pressures significantly; a higher driving pressure increases the velocity of the fluid in the lines and results in a higher surge pressure. The response time of a valve when opening or closing also affects pressure surges in a system by affecting the rate of flow through the valve. Reference 1 discusses plumbing design factors that affect surge pressures.

Surge pressures are typically mitigated using cavitating venturis or sharp-edged orifices welded into the plumbing lines. These mitigation devices are usually upstream of the latch valves but can be located in other parts of the system as needed.

A cavitating venturi includes a taper down to a throat immediately followed by a taper up to the original inner diameter of the line (see Fig. 1). A standard orifice used for the same purpose does not taper like a venturi (see Fig. 2). The tapering of a venturi allows for more pressure recovery downstream of the throat and therefore a lower pressure drop during steady-state flow than an orifice of the same diameter.

\footnotetext{
${ }^{1}$ Propulsion Engineer, NASA GSFC Propulsion Branch, Mail Stop 597, AIAA Member.

${ }^{2}$ Propulsion Engineer, NASA GSFC Propulsion Branch, Mail Stop 597, AIAA Member.
} 


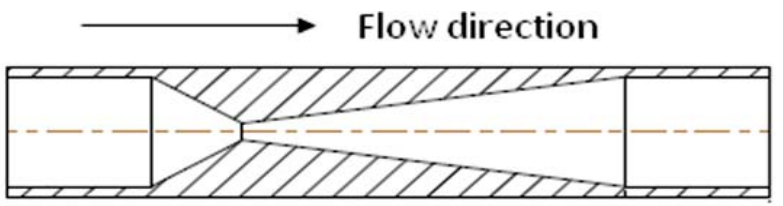

Figure 1. Cross-section of cavitating venturi.

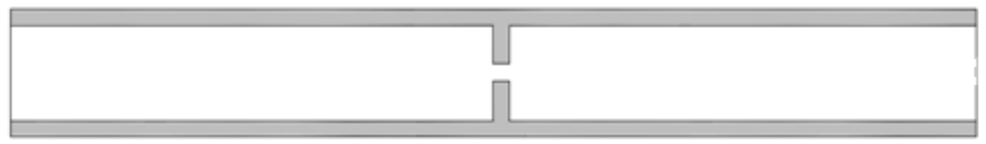

Figure 2. Cross-section of standard orifice.

By design, a cavitating venturi provides a low pressure drop at nominal flow rates and a high pressure drop when the flow rate exceeds the venturi's "cavitation point." The cavitation point is the flow rate at which the static pressure of the fluid at the venturi throat drops below the vapor pressure, creating vapor bubbles in the fluid. The mass flow is highest at the cavitation point, regardless of any additional pressure drop that occurs across the venturi. The venturi throat diameter must be chosen carefully to minimize pressure drop at steady-state flight flow rates for thruster burns but still provide components enough protection from damaging pressure surges.

Cavitating venturis can be sized by analysis, if a propulsion group chooses this method. One analysis tool has been used by the GSFC Propulsion Branch in the past to supplement surge testing. However, GSFC found that this tool does not correctly model surge events for cases in which fluid is flowing into evacuated or partially evacuated manifolds. Thus, this tool is not currently used for flight systems at GSFC; venturis are sized through testing alone.

The current testing method for sizing cavitating venturis is effective but time-consuming for the engineers and technicians involved. Based on previous mission experience, engineers estimate a wide range of venturi sizes and probable locations of the necessary venturis. Necessary portions of the propulsion subsystem are fabricated using ground support equipment in the water hammer test lab. Deionized water is used as a safe alternative to hydrazine. A number of scenarios that mimic both nominal flight situations as well as contingency scenarios are run on this mockup.

In recent years, surge testing has been completed for a number of in-house missions at GSFC. The Solar Dynamics Observatory (SDO) testing, for example, required 368 tests over a span of about 1.5 years. These tests included testing to help understand the water hammer phenomenon, solidify the process for water hammer testing for future missions, and investigate the effects of changes in the plumbing layout. Testing was also performed for the Lunar Reconnaissance Orbiter (LRO). The LRO layout required adjustment of the preferred placement of the cavitating venturis, from downstream of the latch valve to upstream. Locating the venturis downstream of the latch valve created an additional reflected pressure wave from the flow impacting the inlet of the venturi, which exacerbated the pressure surge events. This location change has influenced the venturi location decisions for all GSFC missions since. After the GPM surge testing was completed, engineers and technicians from the GSFC Propulsion Branch also completed testing for the Magnetospheric MultiScale mission (MMS), using lessons learned during previous testing programs. Research toward simplifying the surge testing process has also been completed. A research testing program was completed to better understand the relationship that exists between peak surge pressure and venturi throat diameter. ${ }^{2}$ The goal of this testing program was to provide a quick estimate of a baseline venturi throat diameter for a flight surge pressure testing program.

\section{GPM Mission Overview}

The GPM Core observatory is a satellite that collects state-of-the-art atmospheric rainfall and snowfall measurements to advance Earth Science. GPM aims to increase scientific understanding of the climate and water cycle by taking three-dimensional precipitation measurements over a larger surface area than previous satellites of this type. Upon launch from the Tanegashima Space Center in February 2014, the observatory was placed into a 407-kilometer orbit with a 65-degree inclination that allows readings at the latitudes where nearly all precipitation occurs. GPM takes samples at various times of day and crosses the orbits of other precipitation satellites with similar instruments. In this way, GPM not only provides uniformly calibrated precipitation measurements for most of the areas of the globe, but also serves as a reference standard for a host of other Earth Science satellites in orbit (http://pmm.nasa.gov). 
The observatory was designed, assembled, and tested at the NASA GSFC, with instruments provided by JAXA and NASA. The launch mass was 3,589 kg, including $545 \mathrm{~kg}$ of hydrazine propellant. Figure 3 shows the observatory (with the solar arrays removed).
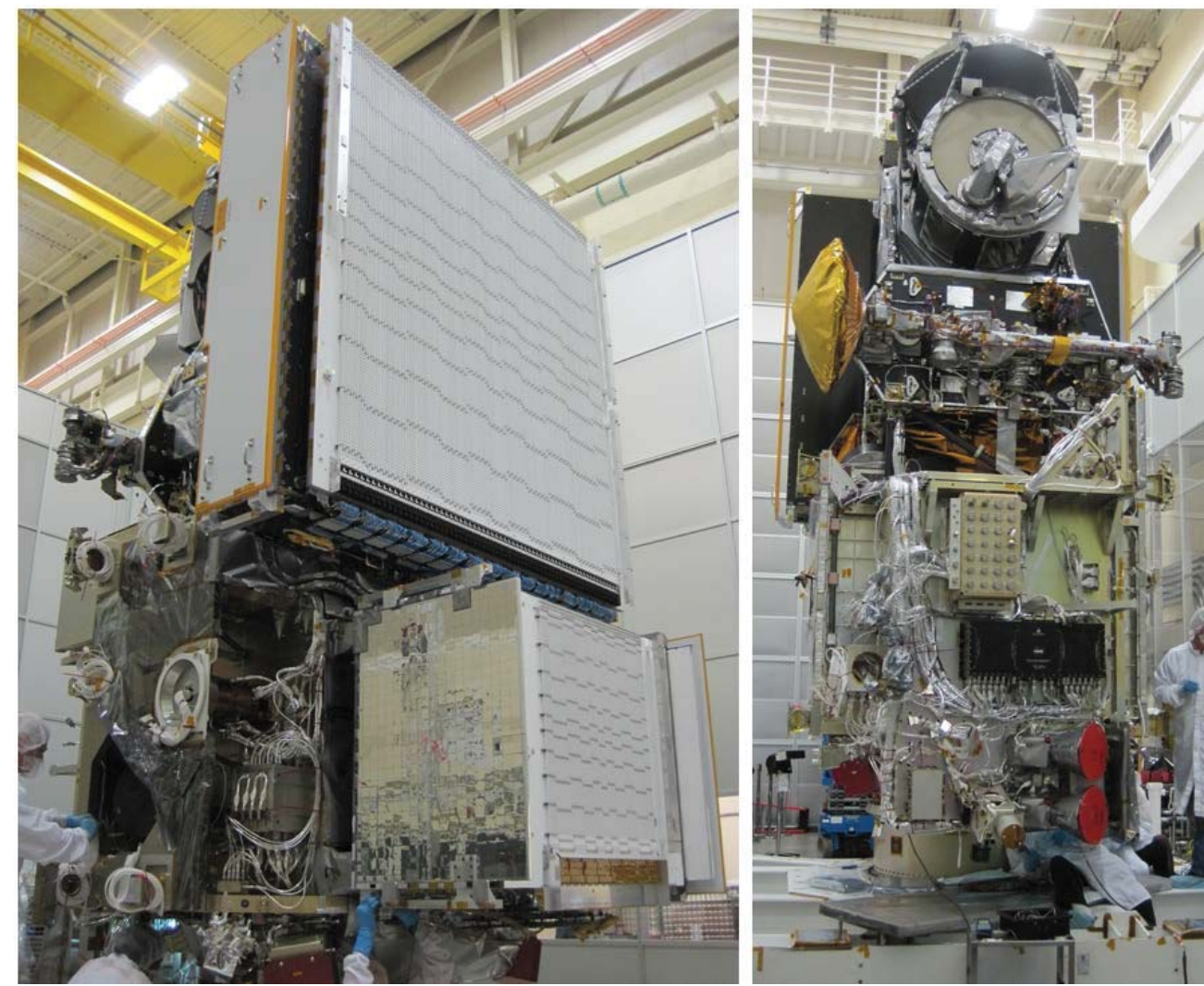

Figure 3. GPM Core observatory.

\section{Propulsion System Design Overview}

The GPM Core observatory contains an on-board propulsion system for orbit maintenance and momentum unloading throughout the 5-year mission goal and for end-of-life satellite disposal. This section contains a short description of the propulsion system fluid design, components, and challenges specific to surge pressure mitigation. For a full discussion of the propulsion system design, assembly, integration, testing, and on-orbit operations, see Ref. 3.

\section{A. Fluid Design}

The propulsion system is a blowdown hydrazine monopropellant system, with the schematic shown in Fig. 4. The maximum expected operating pressure of the system is 400 psia (at $40^{\circ} \mathrm{C}$ ). Pressurization of the liquid propellant is accomplished solely by gas in the propellant tank's ullage. System pressure is highest at launch, and then lowers throughout the mission life as propellant is used and the pressurant gas expands. The thrusters are divided into four manifolds, with a latch valve controlling propellant to each manifold. Tubing between the tank outlet and the latch valves is 0.375 ” outer diameter 304L stainless steel with a wall thickness of 0.028”; all other tubing is 0.25 ” outer diameter 304L stainless steel with a wall thickness of 0.028 ”.

The propulsion system contains a single propellant tank with a surface tension propellant management device (PMD) to provide gas-free propellant to the thruster manifolds in all expected acceleration environments. A propellant filter is located downstream of the propellant tank to protect sensitive latch valve and thruster valve seats from particulate contamination. Pressure knowledge is provided by two pressure transducers located in the gas manifold lines. The system also contains two fill and drain valves, which are plumbed to the inlet and outlet of the propellant tank. 


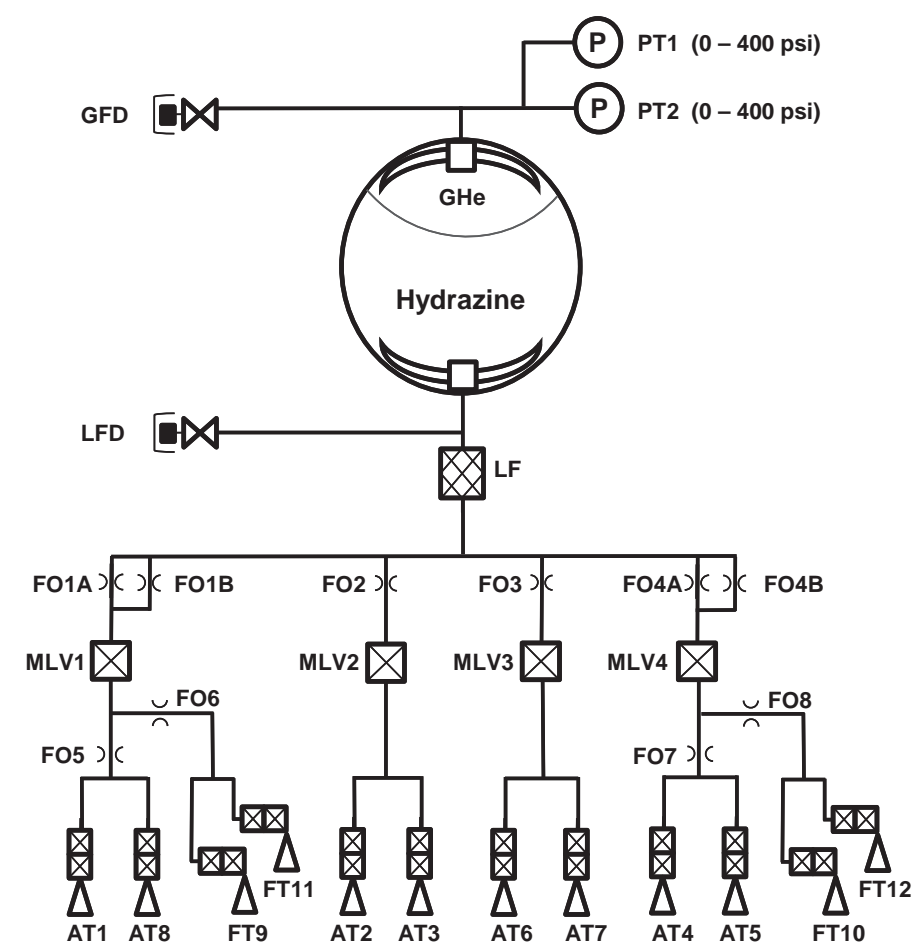

\begin{tabular}{|c|c|}
\hline$[\infty$ & Fill \& Drain Valve \\
\hline$\otimes$ & Liquid Filter \\
\hline & Pressure Transducer \\
\hline 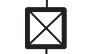 & Latch Valve \\
\hline 水 & Cavitating Venturi \\
\hline 㐫 & Aft Thruster \\
\hline 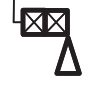 & Forward Thruster \\
\hline$\rightarrow$ & PMD \\
\hline
\end{tabular}

Figure 4. Propulsion system fluid schematic.

The propulsion system consists of an aft module, which mounts to the aft end of the spacecraft structure, and the forward thruster manifolds, which attach to the forward end of the spacecraft with two propellant lines running the length of the observatory (see Fig. 5). Manifolds 1 and 4 contain these long forward propellant lines (226" - 267'), which were found to create high surge pressures. Therefore, these manifolds contain venturis both upstream and downstream of the latch valves. The upstream venturis are configured in parallel to provide surge protection while minimizing pressure drop during thruster operations as described in Section IV (E). Since Manifolds 2 and 3 contain only aft thrusters, a single venturi suffices for each of these manifolds.

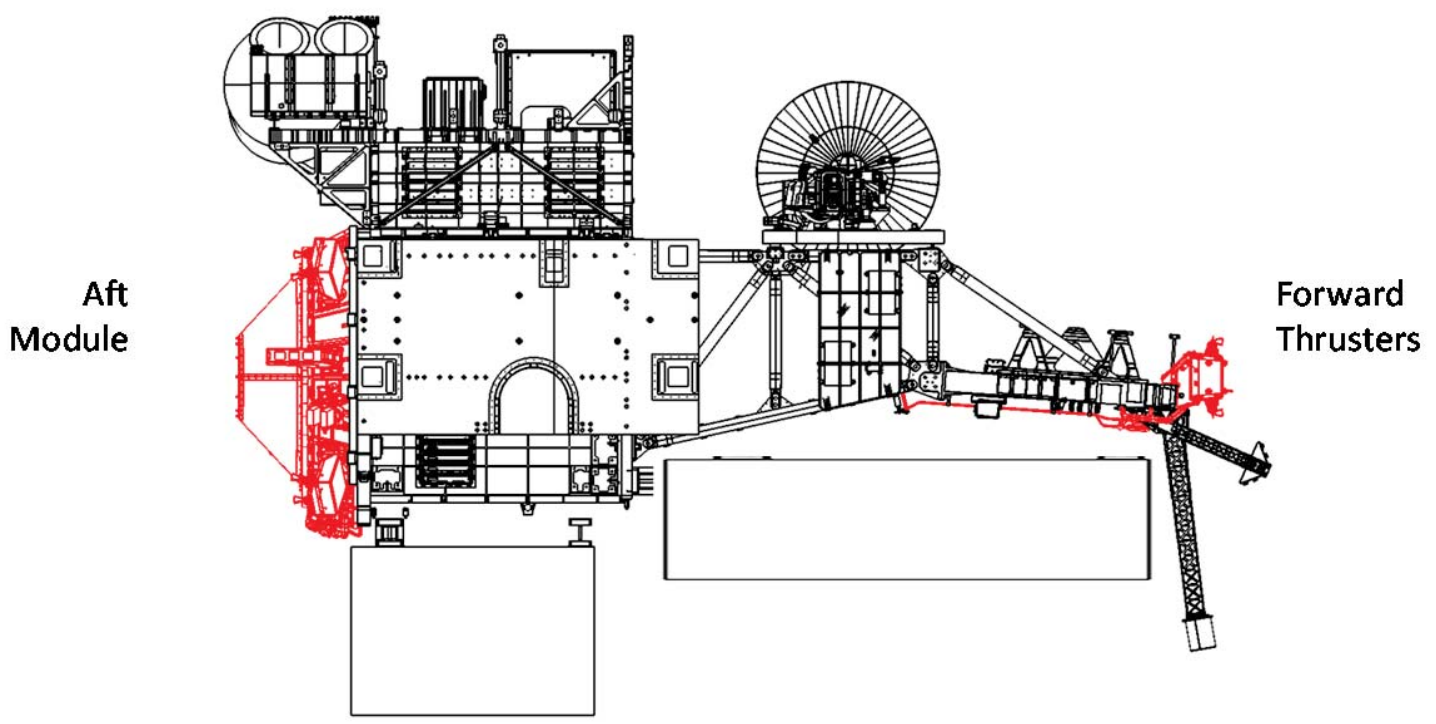

Figure 5. Propulsion system fluid schematic. 


\section{B. Fluid Components}

The propulsion system components are well-proven with flight heritage on many past missions, with the following exceptions. The propellant tank is a new design that involved a technology development program to create a designed-for-demise COPV. ${ }^{4}$ The fill and drain valve design was modified for GPM, and was subjected to a qualification program to verify its flight-worthiness. Table 1 provides key information on the propulsion components.

Table 1. Propulsion system components.

\begin{tabular}{|c|c|c|}
\hline Component & Vendor, Part Number & Major Requirements \\
\hline Pressure Transducers & Taber Industries, P4911C401AGEX5VD & $\begin{array}{l}\text { - Full scale range of } 0-400 \text { psia } \\
\text { - Static error band of } 0.25 \% \text { FSO }\end{array}$ \\
\hline Fill and Drain Valves & ValveTech Incorporated, 17073-1 & $\begin{array}{l}\text { - Operating pressure rating of } 400 \text { psia } \\
\text { - Proof pressure capability of } 600 \text { psia }\end{array}$ \\
\hline Propellant Filter & VACCO Industries, 10230000-01 & $\begin{array}{l}\text { - Operating pressure rating of } 400 \text { psia } \\
\text { - Proof pressure capability of } 750 \text { psia }\end{array}$ \\
\hline Latch Valves & VACCO Industries, V1E10948-04 & $\begin{array}{l}\text { - Operating pressure rating of } 400 \text { psia } \\
\text { - Proof pressure capability of } 825 \text { psia } \\
\text { - Back pressure relief of } 50-150 \text { psid } \\
\text { - Retains position without power }\end{array}$ \\
\hline Propellant Tank & $\begin{array}{l}\text { Cobham Pressure Technology Solutions, } \\
7193\end{array}$ & $\begin{array}{l}\text { - Maximum Design Pressure (MDP) of } 400 \text { psia } \\
\text { - Proof pressure capability of } 500 \text { psia } \\
\text { - Volume of } 0.77 \mathrm{~m}^{3} \text { at MDP } \\
\end{array}$ \\
\hline Thrusters & $\begin{array}{l}\text { AT1 - AT8: Aerojet, MR106L 39626-301 } \\
\text { FT9 - FT12: Aerojet, MR106L 39628-301 }\end{array}$ & $\begin{array}{l}\text { - } 22 \mathrm{~N} \text { class } \\
\text { - Operating pressure range of } 100-400 \text { psia } \\
\text { - Proof pressure capability of 1,500 psia } \\
\text { - Dual-seat thruster valves (series-redundant) }\end{array}$ \\
\hline
\end{tabular}

\section{Launch Configuration}

The launch configuration of the propulsion system was driven by the need to maintain three inhibits to hydrazine leakage. Before launch, the latch valves were kept in the closed position with 25 psia of gaseous helium downstream and liquid hydrazine at 360 psia upstream. The latch valves remained closed until the initial on-orbit checkout of the propulsion system, where they are opened to prime the manifolds with hydrazine. Nominally the latch valves remain open for the entire mission life after this initial priming.

GPM elected to prime the manifolds with the gas present instead of venting through the thruster valves. During priming, the gas acts as a cushion that softens pressure surges. Priming compresses the gas into bubbles that must be ingested through the thrusters during the first several pulses of each thruster. GPM's thruster design has been qualified to ingest gas bubbles 10 times the size of that calculated for GPM without compromising thruster performance or life. Priming manifolds that contain gas poses a risk of adiabatic compression detonation when surge pressures are above 2,500 psia (equivalent in water). ${ }^{1}$ The GPM propulsion system is not susceptible to adiabatic compression detonation due to the cavitating venturi configuration, which reduces surge pressures far below 2,500 psia. 


\section{Surge Challenges for GPM}

Several aspects of the GPM propulsion system design led to surge pressure difficulties.

- Driving pressure during priming. The driving pressure during manifold priming is the full beginning-of-life tank pressure ( 360 psia at nominal tank temperature). Driving pressure has a strong effect on surge pressure. Propulsion systems with separate pressurization systems have the ability to drastically reduce pressure surges by priming thruster manifolds before pressurizing the propellant tanks to full flight pressure.

- Long lines to forward thrusters. The propellant lines that run to the forward thrusters are 226" - 267" long (see Table 2). These long lines tend to experience higher surge pressures than shorter and less voluminous manifolds when being primed. Additionally, two of the four thruster manifolds include both short aft lines and long forward lines. This plumbing design allows high surge pressures from the forward lines to reverberate throughout the manifolds and affect the shorter lines. An early GPM propulsion system design had latch valves for the forward thrusters located at the forward end of the spacecraft, which would have eased the surge pressure challenge. This design was deemed too difficult to accommodate, however, due to the latch valve magnetics affecting forward magnetometers and due to challenges integrating heavier forward hardware to the spacecraft structure.

\section{E. Surge Acceptance Criteria}

Since surge events are very short ( $\sim 20 \mathrm{~ms}$ ), and since the largest surges occur only in failure cases, surge pressures were not taken into account when defining the maximum expected operating pressure for GPM's propulsion system. From a launch range safety standpoint, this approach was acceptable since no surge events were planned during ground operations and launch.

Based on the surge anomaly experienced by the Compton Gamma Ray Observatory, pressure transducer offset and valve damage were considered the most likely failure modes. ${ }^{5}$ Most component manufacturers do not have data on the susceptibility of their designs to surge pressures and do not have qualified surge pressure ratings. All components are proof pressure tested as part of the acceptance testing program, however, so the acceptance criteria for surge pressures were taken to be the proof pressure ratings of the components in the areas affected by surge. Based on test data described in Section IV (E), the most extreme surge pressures occurred at the thruster valves, which have a proof pressure rating of 1,500 psia. Note that the tubing and tube welds in the thruster manifolds were proof tested to 840 psia. However, the tubing and welds demonstrated a burst pressure capability of at least 15,000 psia, so the tubing and welds were assumed insensitive to surge pressures between 840 psia and 1,500 psia.

\section{Surge Pressure Testing Program and Results}

\section{A. Surge Pressure Test Setup}

Surge testing was accomplished using a plumbing mockup built with flight-like tubing designed to match the flight system line lengths. A common assumption for surge testing is that bends and elbows do not affect surge results, ${ }^{1}$ so the tubing was built in two dimensions on an optical bench. A two-dimensional mockup also minimizes gravitational effects. The flight propellant control components were simulated as follows.

- The flight propellant tank was simulated by a laboratory water tank. Although the water tank was volumetrically smaller than the flight tank, it was much larger than the manifold volume. Therefore, the tank acted as a water supply with constant pressure during priming tests.

- For most testing, the liquid fill and drain valve (LFD in Fig. 4) was simulated by a hand valve to provide a dead end in the plumbing. Early testing included a piezoelectric dynamic pressure transducer at this location, but subsequent testing had this sensor moved closer to the latch valve since the flight valves are insensitive to surges. 
- The flight propellant filter (LF in Fig. 4) was not simulated in the surge test setup. The propulsion group did not have an adequate simulator and removing the filter was assumed to be a conservative approach. ${ }^{5}$

- The cavitating venturis used for testing were flight-like units installed using compression fittings. The actual flight venturis were used for the final flight configuration tests.

- The priming latch valve was simulated by a flight spare from the LRO mission. The valve has the same part number as GPM's flight valve, but with a different dash number for minor design changes. This approach simulated the flight valve's opening and flow properties exactly, which is very important to surge testing.

- The thruster locations contained piezoelectric dynamic pressure transducers so as to measure the surge pressure at these locations. Each thruster location also included a hand valve that allowed for manifold purging and evacuation.

The test setup took advantage of symmetry in the plumbing system by using only one of each type (manifold fed through MLV1, "manifold 1," and manifold fed through MLV3, "manifold 3"). These manifolds were selected since they have line lengths greater than or equal to manifold 2 and manifold 4. Figure 6 shows the "configuration A" test setup, which simulates priming of manifold 1. Figure 7 shows the "configuration B" test setup, which simulates priming of manifold 3 .

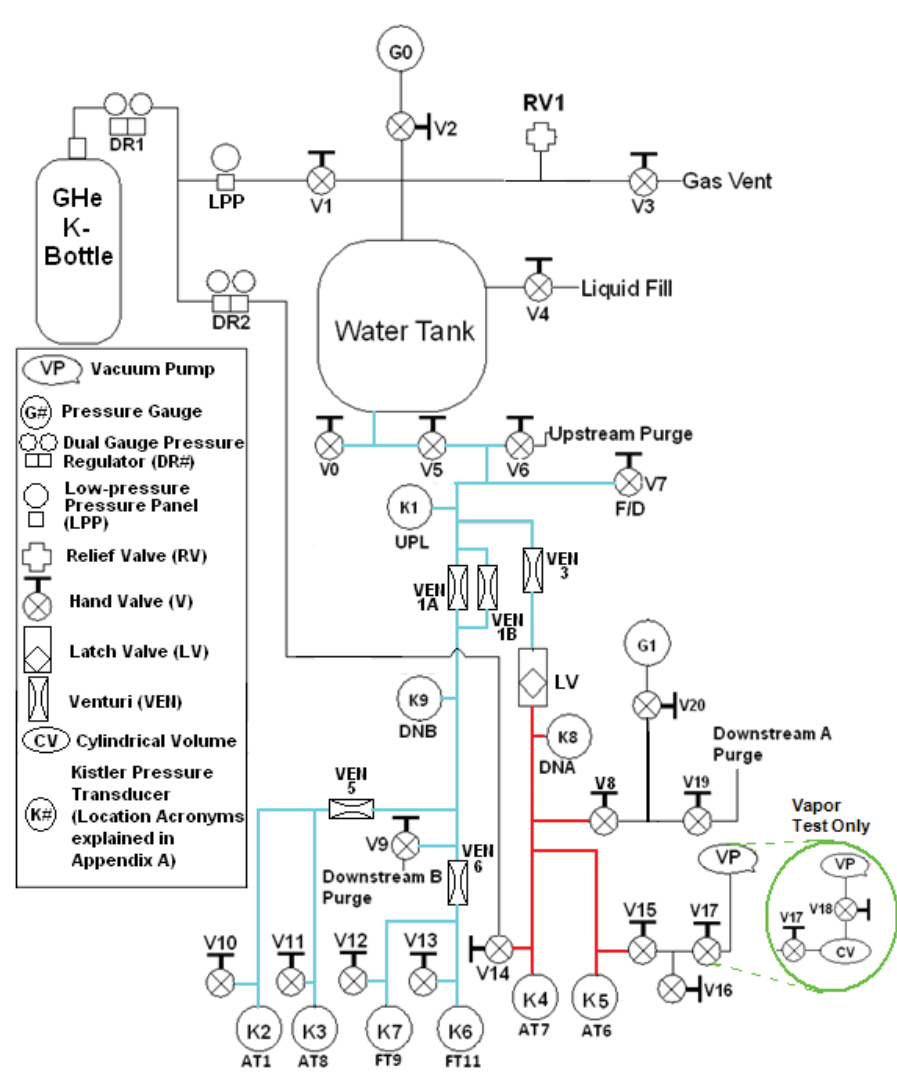

Figure 6. Test setup for configuration A (manifold 1).

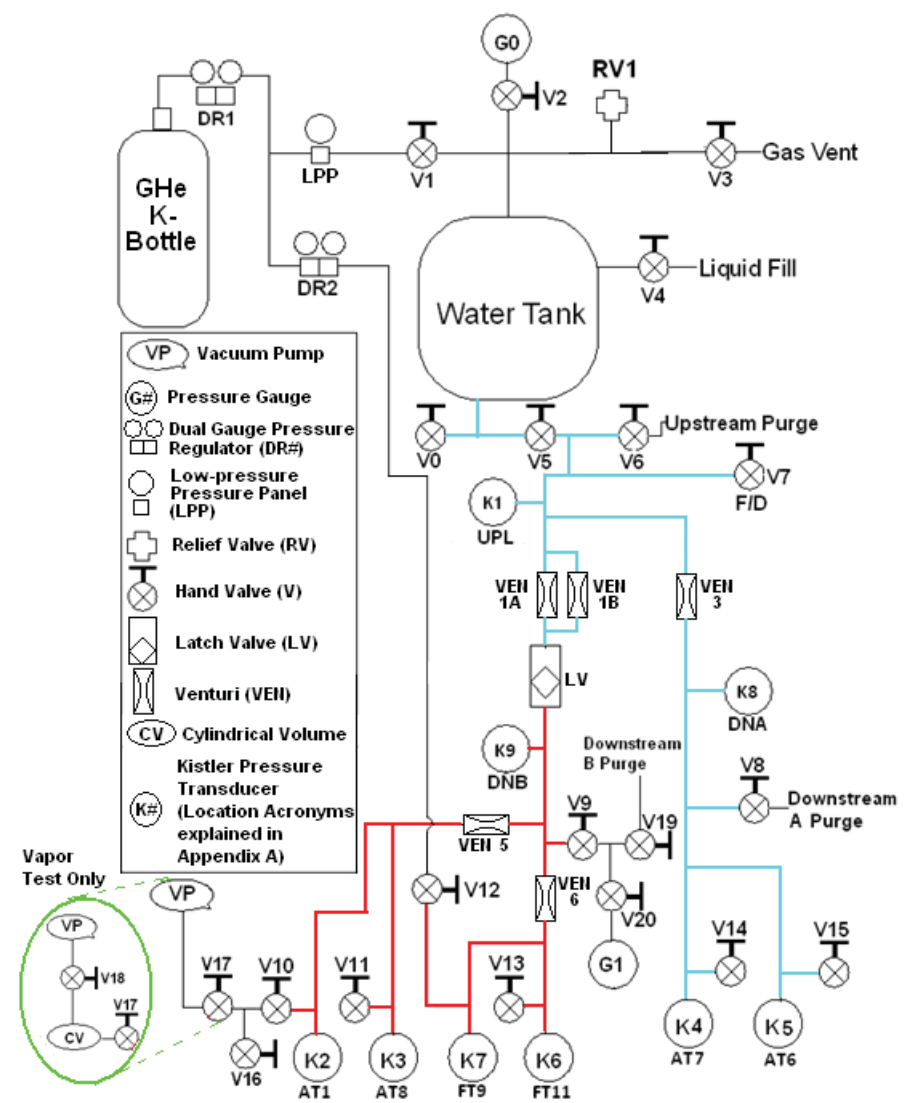

Figure 7. Test setup for configuration B (manifold 3).

\section{B. Test Scenarios}

The surge acceptance criteria must be met in all credible failure scenarios. The driving failure scenario for GPM was that of a leaking thruster. In this case, on-board fault detection and correction would close the latch valve of the leaking thruster to isolate the leak. In the event that this manifold is re-primed, the manifold will be partially or fully evacuated depending on the size of the leak and on the duration that the latch valve was closed. Another failure mode that was considered was that of fault detection and correction closing the latch valves while the thrusters are operating, which would lead to the same partially or fully evacuated manifold. 
Four priming scenarios were tested to cover nominal and credible off-nominal surge events. All four scenarios utilize beginning-of-life upstream pressure of 400 psia, and they differ only in the starting conditions of the manifold tubing downstream of the latch valve as described below.

- Manifolds downstream of the latch valve containing gaseous helium at 25 psia. This scenario represents the launch and initial propulsion system priming configuration. Nominally, this is the only surge event that will occur during the mission life. To achieve this scenario, water is purged from the manifolds, the latch valve is closed, and then the gas is loaded into the downstream lines.

- Manifolds downstream of the latch valve evacuated to 0.2 psia. This scenario represents the failure case in which a thruster valve has leaked all of the manifold's propellant and the manifold must be re-primed. For previous surge test programs at NASA GSFC, this scenario has been the driver for venturi throat diameter choice. To achieve this scenario, water is purged from the manifolds, the latch valve is closed, and then a vacuum pump is connected to the manifold being tested as shown in Fig. 6 and Fig 7.

- Manifolds downstream of the latch valve containing liquid at ambient pressure. This scenario represents the case in which temperature fluctuations and/or latch valve back pressure relief reduce the pressure in a liquid-filled, but isolated, manifold. This is not a nominal case since the latch valves are not planned to be closed on orbit after initial priming of the downstream lines. This test was run after the evacuated scenario above, such that the manifolds started fully charged with water at full system pressure. This scenario was achieved by reducing the system to atmospheric pressure and then closing the latch valve.

- Manifolds downstream of the latch valve containing a liquid-vapor mixture. This scenario represents the failure case in which a thruster valve has leaked a small amount of propellant and the manifold must be reprimed. This test was run after the ambient pressure scenario above such that the manifolds started fully charged with water at full system pressure. This scenario was achieved by reducing the system pressure to atmospheric pressure, closing the latch valve, evacuating a stainless steel gas sampling cylinder, connecting the cylinder to the manifold being tested, and then drawing out liquid to create vapor pockets in the manifold lines. These tests show considerable variability as the amount of water removed and vapor pocket location can be different from test to test.

\section{Water-to-Hydrazine Conversion}

Pressure surges from water tests were converted to equivalent pressure surges in hydrazine using a method described in Ref. 6. The method calculates a water-to-hydrazine relation based on density, bulk modulus of elasticity, and tubing properties. For the GPM propulsion system geometry, hydrazine surge pressures are 34.3\% higher than the observed water surge pressures.

\section{Pressure Drop Analysis Background}

AFT Fathom Version 8.0 was used to complete the pressure drop analysis. A model of the propulsion system was created in the Fathom tool, including each line and component. The final flight model is shown in Fig. 8. Fathom calculates the pressure drop across each component and line, based on the specifications input into the model, which are then summed to provide the total pressure drop from the tank to the thrusters.

The tank pressure was modeled as ranging from $100-400$ psia in approximately 50 psia increments, thus simulating the mission life. The original analysis included five scenarios shown below. Additional scenarios were included later, based on specific plans for thruster usage during flight.

- All eight aft thrusters firing simultaneously

- All four forward thrusters firing simultaneously

- All twelve thrusters firing simultaneously

- Six thrusters firing simultaneously - four forward thrusters and two aft thrusters

- Eight thrusters firing simultaneously - four forward thrusters and four aft thrusters (4x4)

The pressure drop analysis was used in conjunction with the blowdown analysis to help determine thruster performance and expected propellant usage through the mission lifetime. All twelve thrusters will not fire steadystate simultaneously, but it is possible to have the forward thrusters firing steady-state and the aft thrusters plumbed in the same manifolds on-pulsing for attitude control. The 4x4 and 6-thruster scenarios are similar in that they illustrate system behavior with all forward thrusters firing steady-state and four or two aft thrusters on-pulsing for attitude control. 


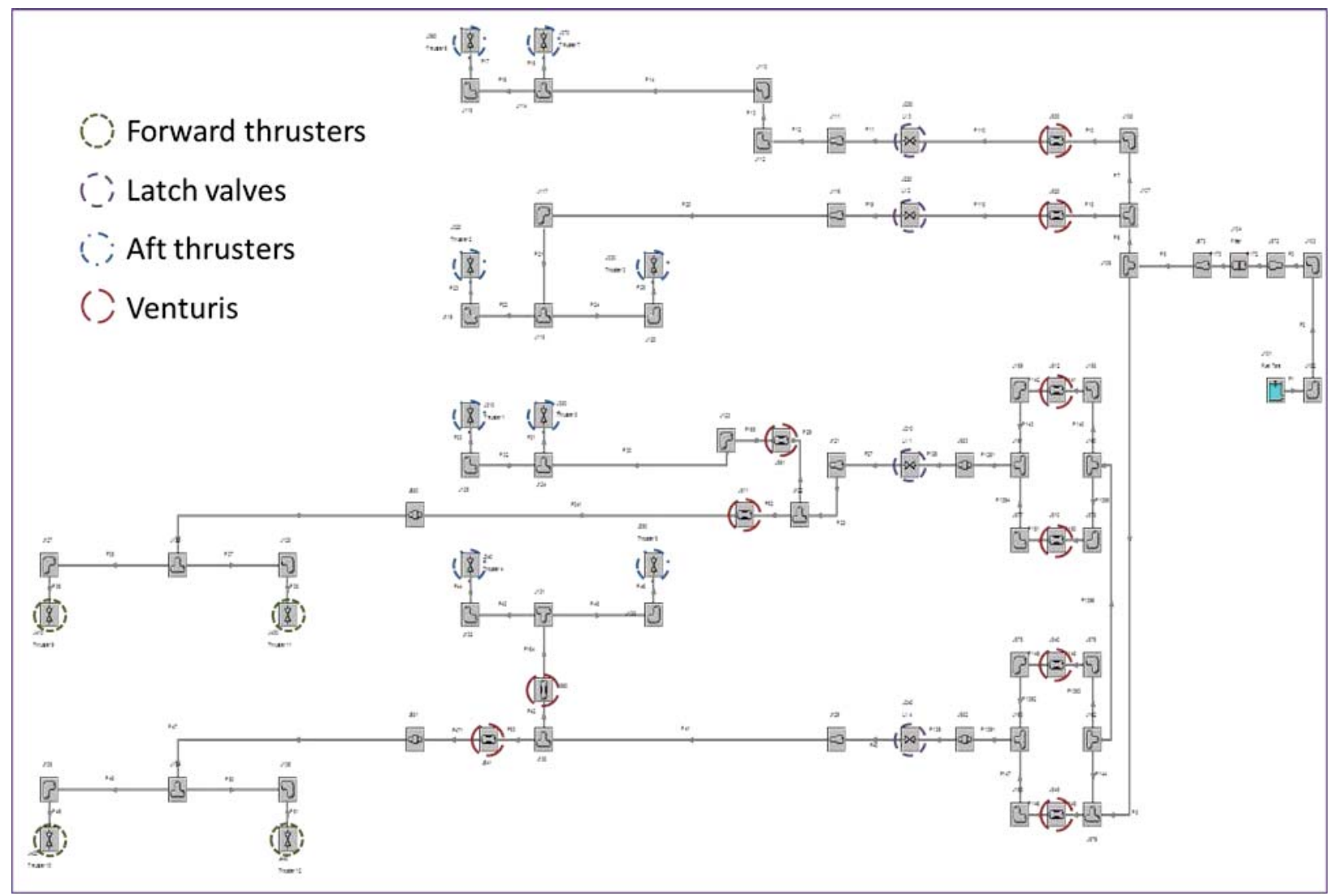

Figure 8. Pressure drop model.

For GPM, the venturi configuration and sizing were determined by finding a balance between surge pressure testing and thruster performance during steady-state firings, which is highly affected by the amount of pressure drop through the system. In past missions, surge pressure has been the driving factor and the pressure drop in the system is accepted for the mission, provided it will not cause a decrease in thruster performance that is unacceptable from the standpoint of maneuver planning or propellant budgeting. Overall system pressure drop results commonly fall in the $10-20$ psid range for GSFC missions. The largest venturi size acceptable to mitigate pressure surges is typically chosen in order to minimize the pressure drop during steady-state thruster burns.

\section{E. Venturi Configurations - Testing and Analysis}

The initial configuration chosen for GPM surge mitigation was one venturi immediately upstream of each of the four latch valves. Venturis with throat diameters of 0.048 ”, 0.050 ”, and 0.055 ” were selected for testing based on configurations that were successful on previous missions. The test results for the 0.048 ” venturi are shown in Table 3. None of the venturi sizes successfully mitigated pressure surges to the extent needed, keeping pressure surges below 1,500 psi in all tested scenarios.

Pressure drop analysis was performed in parallel with the initial water hammer testing. A venturi diameter of 0.055 " was chosen for analysis, based on the predicted steady-state flight flow rates. For this configuration, two scenarios were analyzed to establish a baseline: all 8 aft thrusters firing simultaneously and all 4 forward thrusters firing simultaneously. The analysis resulted in the pressure drop values shown in Fig. 9, with a maximum pressure drop of 12 psid.

Since the surge test results were unsatisfactory, the venturis were moved to a location immediately downstream of each latch valve. The 0.050 " and 0.048 " venturis were tested in this configuration, but the surge results remained higher than the allowable 1,500 psia. Pressure drop analysis was not performed for venturis downstream of the latch valve because the test results did not meet the requirements. 
Table 3. 0.048" venturi upstream of latch valve test results.

\begin{tabular}{|c|c|c|c|c|c|c|c|c|c|}
\hline \multirow{2}{*}{$\begin{array}{c}\text { Test } \\
\text { Configuration }\end{array}$} & \multirow{2}{*}{$\begin{array}{l}\text { Venturi } \\
\text { Size }\end{array}$} & \multirow[b]{2}{*}{ Test Scenario } & \multicolumn{7}{|c|}{ Water to Hydrazine Corrected Surge Pressure [psia] } \\
\hline & & & F/D & AT1 & AT8 & AT7 & AT6 & FT11 & FT9 \\
\hline A & $0.048 "$ & $\begin{array}{l}415 \text { psia liquid upstream; } \\
25 \mu \text { vacuum downstream } \\
\end{array}$ & 661 & 827 & 1,323 & 1,691 & 1,741 & 977 & 785 \\
\hline A & $0.048 "$ & $\begin{array}{c}415 \text { psia liquid upstream; } \\
\text { ambient pressure liquid downstream }\end{array}$ & 763 & 944 & 977 & 2,015 & 1,901 & 1,205 & 1,147 \\
\hline A & $0.048 "$ & $\begin{array}{c}415 \text { psia liquid upstream; } \\
\text { liquid-vapor mixture downstream }\end{array}$ & 688 & 867 & 904 & 1,794 & 1,689 & 985 & 898 \\
\hline B & $0.048 "$ & $\begin{array}{l}415 \text { psia liquid upstream; } \\
25 \mu \text { vacuum downstream } \\
\end{array}$ & 731 & 1,912 & 1,805 & 946 & 1,039 & 1,654 & 1,975 \\
\hline B & $0.048 "$ & $\begin{array}{l}415 \text { psia liquid upstream; } \\
\text { ambient pressure liquid downstream }\end{array}$ & 757 & 1,216 & 1,062 & 868 & 909 & 1,638 & 1,609 \\
\hline B & $0.048 "$ & $\begin{array}{l}415 \text { psia liquid upstream; } \\
\text { liquid-vapor mixture downstream }\end{array}$ & 752 & 1,941 & 1,865 & 938 & 1,104 & $\mathbf{1 , 7 8 7}$ & 1,719 \\
\hline
\end{tabular}

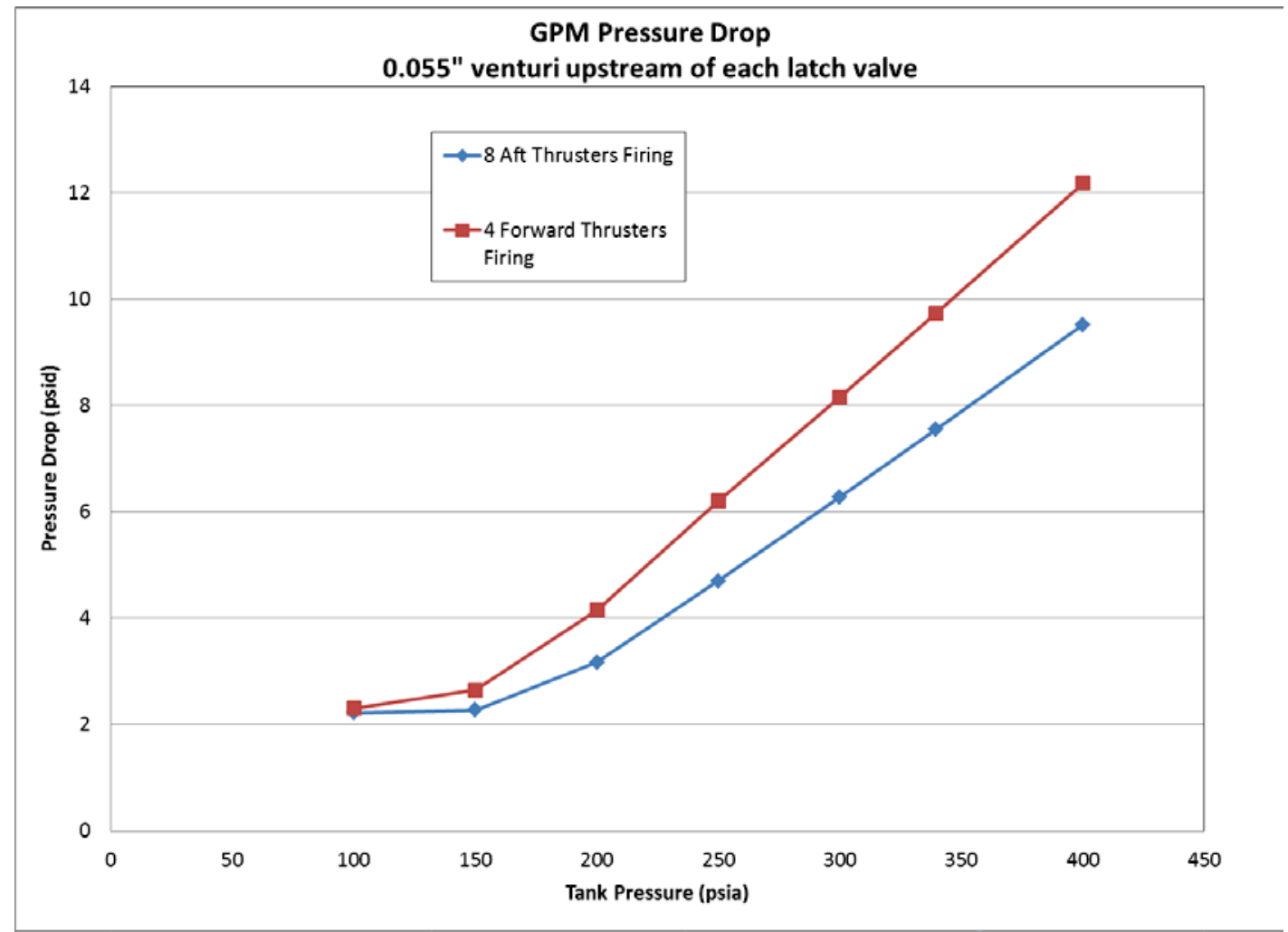

Figure 9. 0.055” venturi upstream of latch valve pressure drop results.

Because the surge testing results were still too high, troubleshooting was required to determine system behavior with different venturi configurations. One theory used in troubleshooting was that the long forward lines were affecting the pressure surges in the aft manifolds. In order to isolate the pressure surges in the forward and aft lines, venturis were added to the forward manifolds downstream of the latch valve. Venturis were also placed upstream of each latch valve to continue to provide additional protection for the components. Multiple configurations of different venturi sizes and locations were tested.

A configuration that included a 0.045 ” venturi upstream of each latch valve, as well as a 0.043 ” venturi in each of the forward manifolds, resulted in a maximum pressure surge of 1,399 psia (see Table 4). This configuration was recommended as acceptable for flight based on surge test data. 
Table 4. 0.045 ” venturi upstream of latch valve, 0.043 ” venturi in forward lines surge test results.

\begin{tabular}{|c|c|c|c|c|c|c|c|c|c|c|c|}
\hline \multirow{2}{*}{$\begin{array}{c}\text { Test } \\
\text { Configuration }\end{array}$} & \multirow{2}{*}{$\begin{array}{l}\text { Venturi } \\
\text { Size }\end{array}$} & \multirow[b]{2}{*}{ Test Scenario } & \multicolumn{9}{|c|}{ Water to Hydrazine Corrected Surge Pressure [psia] } \\
\hline & & & UPL & AT1 & AT8 & AT7 & AT6 & FT11 & FT9 & DNA & DNB \\
\hline A & $\begin{array}{c}0.045 " \\
\text { upstream }\end{array}$ & $\begin{array}{l}415 \text { psia liquid upstream; } \\
25 \mu \text { vacuum downstream }\end{array}$ & 722 & 996 & 835 & 940 & 994 & 812 & 764 & 1,038 & 772 \\
\hline A & $\begin{array}{c}0.045 " \\
\text { upstream }\end{array}$ & $\begin{array}{c}415 \text { psia liquid upstream; } \\
\text { ambient pressure liquid downstream }\end{array}$ & 821 & 954 & 882 & 1,399 & 1,340 & 981 & 878 & 1,102 & 852 \\
\hline A & $\begin{array}{c}0.045 " \\
\text { upstream }\end{array}$ & $\begin{array}{l}415 \text { psia liquid upstream; } \\
\text { liquid-vapor mixture downstream }\end{array}$ & 743 & 875 & 837 & 1,328 & 1,357 & 842 & 768 & 1,023 & 741 \\
\hline B & $\begin{array}{c}0.045 " \\
\text { upstream; } \\
0.043 " \text { in } \\
\text { FT lines } \\
\end{array}$ & $\begin{array}{l}415 \text { psia liquid upstream; } \\
25 \mu \text { vacuum downstream }\end{array}$ & 687 & 964 & 922 & 861 & 889 & 1,146 & 1,038 & 720 & 775 \\
\hline B & $\begin{array}{c}0.045 " \\
\text { upstream; } \\
0.043 " \text { in } \\
\text { FT lines } \\
\end{array}$ & $\begin{array}{l}415 \text { psia liquid upstream; } \\
\text { ambient pressure liquid downstream }\end{array}$ & 744 & 1,168 & 1,094 & 883 & 911 & 1,313 & 1,325 & 782 & 925 \\
\hline B & $\begin{array}{c}0.045 " \\
\text { upstream; } \\
0.043 " \text { in } \\
\text { FT lines }\end{array}$ & $\begin{array}{l}415 \text { psia liquid upstream; } \\
\text { liquid-vapor mixture downstream }\end{array}$ & 700 & 1,073 & 1,041 & 882 & 938 & 1,254 & 1,090 & 767 & 925 \\
\hline
\end{tabular}

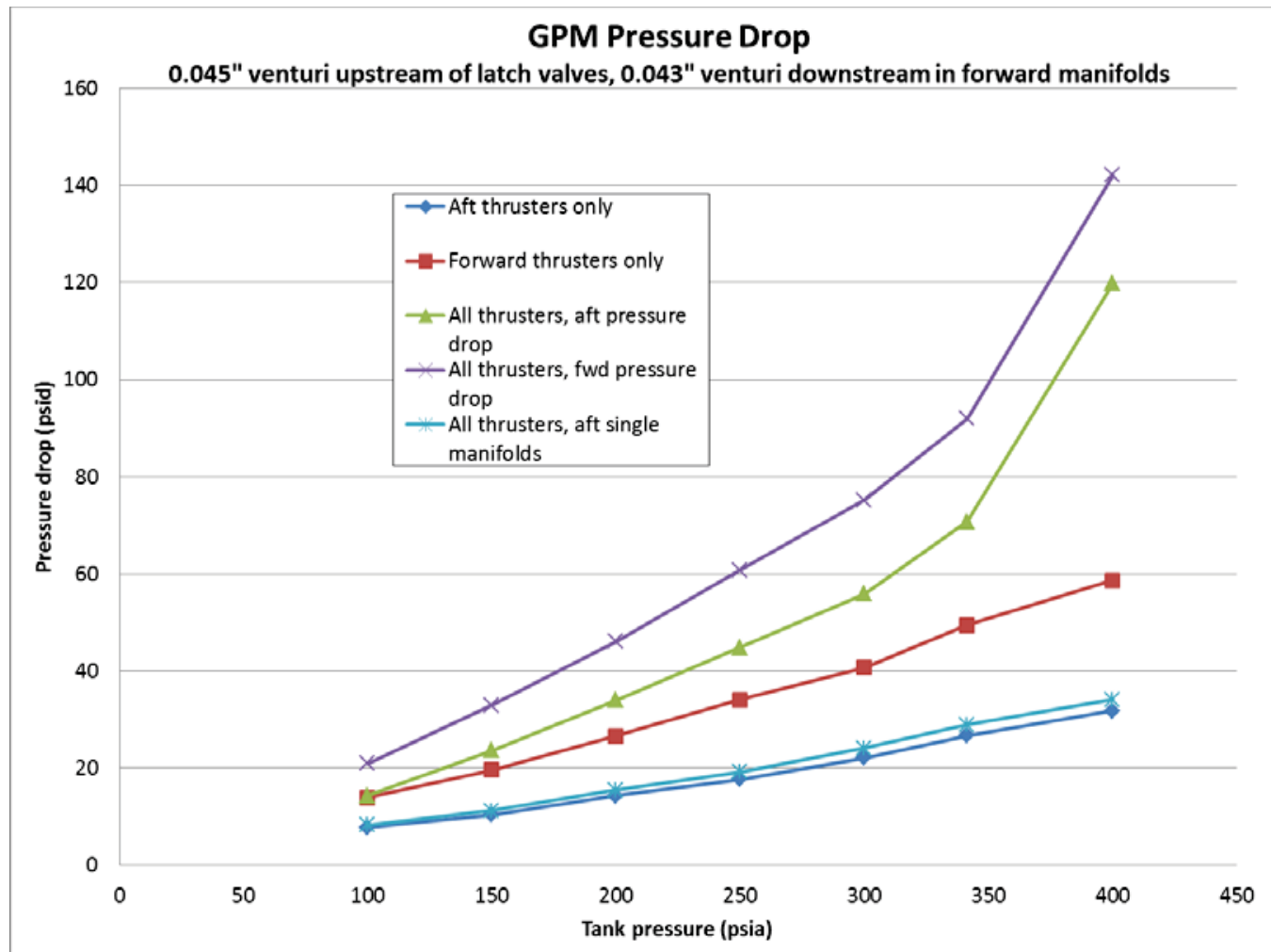

Figure 10. 0.045 ” venturi upstream of latch valve, 0.043 ” venturi in forward lines pressure drop results.

Pressure drop analysis was performed for the recommended venturi configuration. The results are shown in Fig. 10. These results show that any situation including all twelve thrusters is unacceptable for pressure drop and would significantly impact thruster performance. In these cases, the flow rate through the venturis caused cavitation during steady-state flow at high tank pressures, resulting in extreme pressure drop.

Upon investigating the pressure drop analysis results from multiple thruster firing configurations, it was apparent that the manifolds that included forward thrusters were the manifolds in which the pressure drop was too high. When 
any scenario included both aft and forward thrusters firing from the same manifold, the mass flow through the venturis became too high, causing the venturis to cavitate or to approach their cavitation points. The surge pressures were also highest in the forward lines because of their long lengths.

Based on this understanding of the test and analysis results, engineers determined that by inserting venturis in these manifolds in parallel and upstream of the latch valve, the mass flow through the venturis would be cut in half, thus preventing cavitation during steady-state flow while still allowing cavitation during surge events. This approach had not been attempted previously for a GSFC mission. The first test scenarios used 0.045 ” and 0.050 " venturis installed in parallel upstream of the latch valve for manifolds that included forward thrusters. The maximum surge pressure was 3,340 psia, well above the allowed 1,500 psia. However, pressure drop analysis results were promising. The maximum pressure drop with all thrusters firing was 47.3 psid in the forward manifolds. Another round of surge tests was conducted to investigate configurations with upstream venturis in parallel, including test configurations with venturis in both the aft lines and forward lines downstream of the latch valve.

The configuration chosen for flight includes two 0.048 " venturis in parallel upstream of the two latch valves with forward manifolds, a 0.035 " venturi downstream of the latch valve in the forward lines, and a 0.043 " venturi downstream of the latch valve in the aft lines. In the manifolds without forward thrusters, a 0.045 ” venturi is installed upstream of the latch valve. These venturi sizes were ordered for flight, and the surge testing was repeated when the venturis were received. The maximum surge pressures met the requirements (see Table 5), and the venturis were accepted for flight.

Table 5. Flight venturi configuration surge test results.

\begin{tabular}{|c|c|c|c|c|c|c|c|c|c|c|c|}
\hline \multirow{2}{*}{$\begin{array}{c}\text { Test } \\
\text { Configuration }\end{array}$} & \multirow{2}{*}{ Venturi Size } & \multirow{2}{*}{ Test Scenario } & \multicolumn{9}{|c|}{ Water to Hydrazine Corrected Surge Pressure [psia] } \\
\hline & & & UPL & AT1 & AT8 & AT7 & AT6 & FT11 & FT9 & DNA & DNB \\
\hline A & 0.045" upstream & $\begin{array}{c}415 \text { psia liquid upstream; } \\
10 \text { psig ullage gas downstream }\end{array}$ & 620 & 794 & 731 & 591 & 602 & 739 & 701 & 555 & 571 \\
\hline A & 0.045" upstream & $\begin{array}{l}415 \text { psia liquid upstream; } \\
25 \mu \text { vacuum downstream }\end{array}$ & 698 & 854 & 825 & 1,226 & 1,440 & 806 & 831 & 874 & 560 \\
\hline A & 0.045" upstream & $\begin{array}{l}415 \text { psia liquid upstream; } \\
\text { ambient pressure liquid downstream }\end{array}$ & 635 & 822 & 761 & 795 & 812 & 744 & 703 & 688 & 560 \\
\hline A & 0.045" upstream & $\begin{array}{c}415 \text { psia liquid upstream; } \\
\text { liquid-vapor mixture downstream }\end{array}$ & 818 & 995 & 946 & 1,223 & 1,443 & 1,051 & 975 & 1,172 & 560 \\
\hline B & $\begin{array}{c}\text { 0.048" parallel upstream; } \\
0.043 \text { " in AT lines; } \\
0.035 \text { "in FT lines }\end{array}$ & $\begin{array}{c}415 \text { psia liquid upstream; } \\
10 \text { psig ullage gas downstream }\end{array}$ & 633 & 555 & 574 & 563 & 561 & 553 & 536 & 564 & - \\
\hline B & $\begin{array}{c}\text { 0.048" parallel upstream; } \\
0.043 \text { "in AT lines; } \\
\text { 0.035" in FT lines }\end{array}$ & $\begin{array}{l}415 \text { psia liquid upstream; } \\
25 \mu \text { vacuum downstream }\end{array}$ & 765 & 1,222 & 1,259 & 567 & 570 & 957 & 870 & 569 & - \\
\hline B & $\begin{array}{c}\text { 0.048" parallel upstream; } \\
0.043 \text { "in AT lines; } \\
0.035 \text { "in FT lines } \\
\end{array}$ & $\begin{array}{l}415 \text { psia liquid upstream; } \\
\text { ambient pressure liquid downstream }\end{array}$ & 742 & 1,105 & 1,017 & 561 & 563 & 1,089 & 1,157 & 564 & - \\
\hline B & $\begin{array}{c}\text { 0.048" parallel upstream; } \\
0.043 \text { " in AT lines; } \\
0.035 \text { "in FT lines }\end{array}$ & $\begin{array}{l}415 \text { psia liquid upstream; } \\
\text { liquid-vapor mixture downstream }\end{array}$ & 857 & 1,196 & 1,180 & 567 & 561 & 1,121 & 1,137 & 561 & - \\
\hline
\end{tabular}




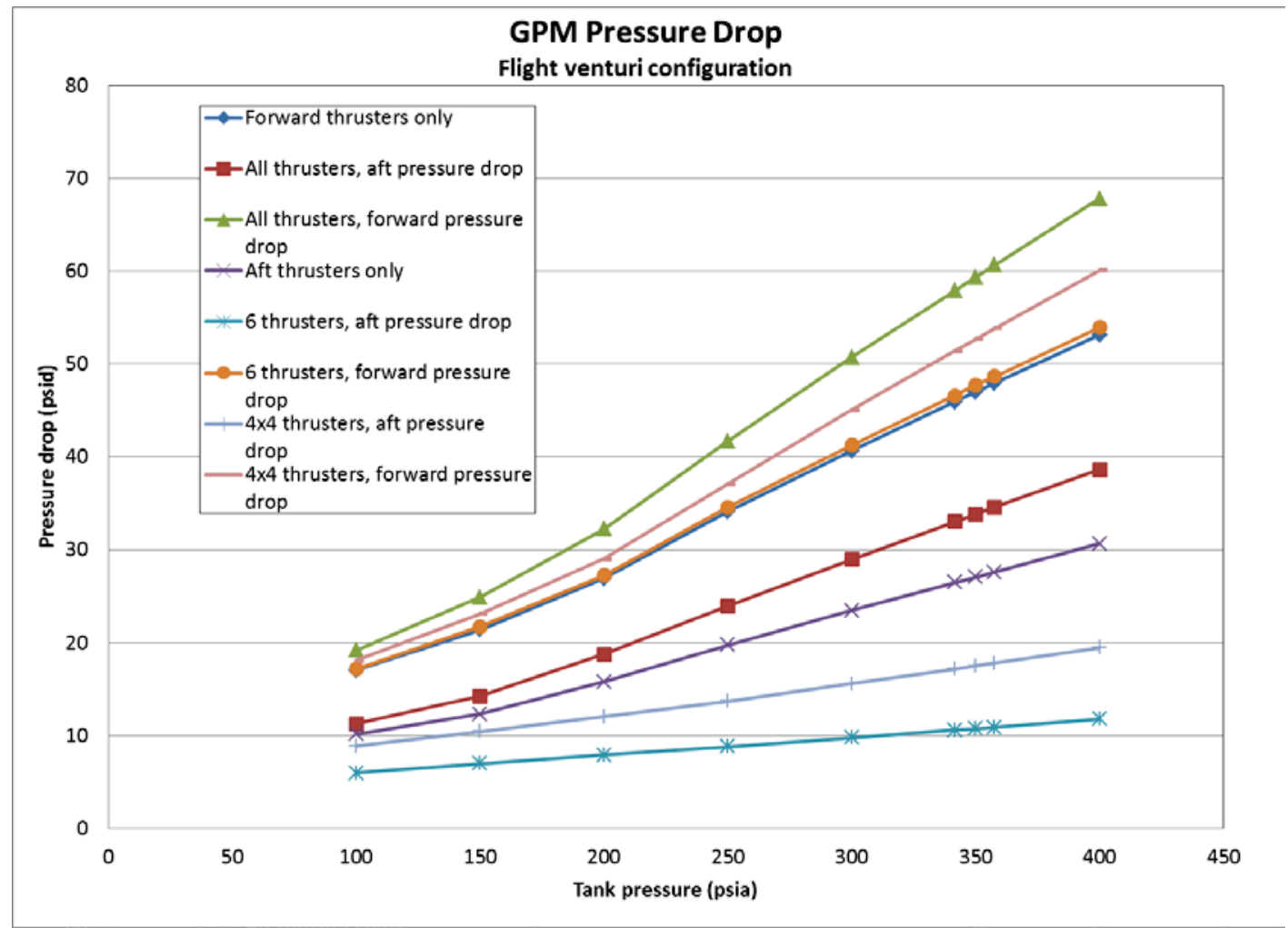

Figure 11. Flight venturi configuration pressure drop results.

On orbit, a maximum of four thrusters will be firing at any one time, and no configurations require both forward thrusters and both aft thrusters from the same manifold. Avoiding this scenario prevents the pressure drop from reaching the highest values shown in Fig. 11. The pressure drop analysis showed that the pressure drop through the system was still higher than previous missions, but the venturis were not cavitating during steady-state flow. The pressure drop could be accepted for this mission for the following reasons.

- The scenario with the highest pressure drop is not very likely to occur in flight, and would only occur momentarily. Thus, it should not significantly affect thruster performance.

- Higher pressure drop only occurs at the beginning of the mission, when the driving pressure is at its highest. Therefore, at end of life, when thruster performance is more critical for reentry maneuvers, the pressure drop would be acceptably low.

- No other solutions had been found that would both result in lower steady-state pressure drop and successfully mitigate surge pressures.

\section{On-Orbit Performance}

Upon reaching orbit in February 2014, the latch valves were opened sequentially starting with MLV1 and ending with MLV4. The time between latch valve actuations was $3-4$ minutes. The tank pressure driving manifold priming was 356 psia. Since the flight pressure transducers are located on the gas side of the propellant tank, no surge pressures were observed. No negative effects were observed after priming, with the thruster valves, latch valves, and pressure transducers performing nominally. The propulsion system operated through thirteen orbit maintenance maneuvers, with thrusters showing nominal performance. System pressure drop has been as-expected through both maneuvers using aft thrusters and maneuvers using forward thrusters and no cavitation has been suspected. The propellant tank pressure will decrease further throughout the mission such that the pressure drop will carry less of an effect on thruster performance. 


\section{Surge Pressure Mitigation Lessons Learned}

Throughout the GPM surge test program, several key lessons were learned.

- Since GPM's propulsion system had known surge susceptibilities, surge mitigation overshadowed the pressure drop results for the proposed venturi sizes during early testing. At one point during the test program, a venturi configuration with acceptable surge mitigation was later found to be unacceptable due to high steady-state pressure drop. For future projects, pressure drop analyses should be performed in parallel with defining orifice/venturi sizing.

- Since procuring venturis and performing surge tests is time-consuming and expensive, pressure drop criteria should be clearly defined to ensure an efficient surge test program.

- Nominal and worst-case thruster firing combinations should be identified as early as possible. Performing pressure drop analyses using unrealistic firing combinations results in overly conservative venturi configurations.

- Gas in the downstream manifold lines at launch effectively mitigates surge pressures. Although compressing gas during priming carries a risk of adiabatic compression decomposition, the GPM propulsion system's long forward lines made the configuration advantageous, reducing the resultant surge pressures such that decomposition was a non-credible risk.

- Venturis in parallel allow for surge mitigation with less overall pressure drop.

- For NASA GSFC flight projects, using a flight spare latch valve for surge testing provided a high-fidelity substitute for the actual latch valve in both flow characteristics and opening time. These parameters are important to surge results.

\section{Conclusion}

The GPM propulsion system plumbing design carried a risk of particularly high surge pressures, but the surge test program identified a flight configuration that is acceptable with regard to both surge mitigation and steady-state system pressure drop. Due to long forward thruster propellant lines and a necessarily high driving pressure during manifold priming, standard venturi configurations could not provide an acceptable solution. The flight configuration involves an array of venturis, with smaller venturis protecting long forward lines and larger venturis protecting manifold lines with less extreme surge pressures. This configuration maintains surge protection for the whole system with above average pressure drop affecting only selected thrusters.

\section{Acknowledgments}

The authors recognize the engineers and technicians who helped with the surge pressure tests, component pressure drop tests, and pressure drop analyses described in this paper: Hal Baesch, Kyle Bentley, Stephen Graham, Stephen McKim, Kris Romig, Graham Webster, and Mike Wilks. Special recognition is also given to Ricky Burcat, who led a great deal of this testing and contributed to this paper.

\section{References}

${ }^{1}$ AIAA, "Fire, Explosion, Compatibility, and Safety Hazards of Hypergols - Hydrazine,” Special Project Report AIAA SP084-1999, AIAA, Reston, VA, 1999, pp. 53-57.

${ }^{2}$ Scroggins, A. R., “A Streamlined Approach to Venturi Sizing," $48^{\text {th }}$ AIAA Joint Propulsion Conference, Paper AIAA 20124028, AIAA, Reston, VA, 2012.

${ }^{3}$ Fiebig, M. D. and Bacha, C. A., "Design and Testing of the Global Precipitation Measurement Mission Core Propulsion System,” 49 ${ }^{\text {th }}$ AIAA Joint Propulsion Conference, Paper AIAA 2013-3758, AIAA, Reston, VA, 2013.

${ }^{4}$ Estes, R. H., Harris, J., and Moore, N. R., "Summary of the Development of a Demiseable Composite Overwrapped Hydrazine Tank for the Global Precipitation Measurement Mission from Concept to Delivery,” $48^{\text {th }}$ AIAA Joint Propulsion Conference, Paper AIAA 2012-4045, AIAA, Reston, VA, 2012.

${ }^{5}$ Dressler, G., et al., “Compton Gamma Ray Observatory: Lessons Learned in Propulsion,” 37 ${ }^{\text {th }}$ AIAA Joint Propulsion Conference, Paper AIAA 2001-3631, AIAA, Reston, VA, 2001.

${ }^{6}$ Prickett, R. P., Mayer, E., and Hermel, J., “Water Hammer in a Spacecraft Propellant Feed System,” 24 ${ }^{\text {th }}$ AIAA Joint Propulsion Conference, Paper AIAA-88-2920, AIAA, Reston, VA, 1988. 